PNL-SA-23975

\title{
COMPREHENSIVE FACILITY ENERGY ASSESSMENT USING FEDS
}

D. L. Hadley

J. M. Keller

E. E. Richman

R. Quinones ${ }^{(n)}$

December 1994

Presented at the

World Energy Engineering Congress Conference

December 7-9, 1994

Atlanta, Georgia

Prepared for

the U.S. Department of Energy

under Contract DE-AC06-76RLO 1830

Pacific Northwest Laboratory

Richland, Washington 99352

(a) Energy \& Demand Savings Opportunities, Fort Irwin, California

\section{DISCLAIMER}

This report was prepared as an account of work sponsored by an agency of the United States Government. Neither the United States Government nor any agency thereof, nor any of their employees, makes any warranty, express or implied, or assumes any legal liability or responsibility for the accuracy, completeness, or usefulness of any information, apparatus, product, or process disclosed, or represents that its use would not infringe privately owned rights. Reference herein to any specific commercial product, process, or service by trade name, trademark, manufacturer, or otherwise does not necessarily constitute or imply its endorsement, recommendation, or favoring by the United States Government or any agency thereof. The views and opinions of authors expressed herein do not necessarily state or reflect those of the United States Government or any agency thereof. 


\section{DISCLAIMER}

Portions of this document may be illegible in electronic image products. Images are produced from the best available original document. 


\title{
COMPREHENSIVE FACIUITY ENERGY ASSESSMENT USING FEDS
}

\author{
Donald L. Hadley \\ John M. Keller \\ Eric E. Richman \\ Pacific Northwest Laboratory \\ Rene Quinones \\ Fort Irwin
}

\begin{abstract}
The energy savings and demand reduction opportunities at the Army's National Training Center at Fort Irwin, California, were evaluated. The Fort Irwin analysis made use of the recently developed Facility Energy Decision Screening (FEDS) System Level-2 software tool. FEDS is a systematic, technology-neutral, and fuel-neutral approach to evaluating energy savings opportunities at large facilities. FEDS analyzes most major building end uses (e.g., heating, cooling, lighting, ventilation, and service hot water), including interactive effects (e.g., the effect of a lighting technology on heating and cooling loads). FEDS output provides specific cost, energy (and demand) charges, and life-cycle cost (LCC) information, by cost-effective energy resource opportunities (EROs). The remaining end uses common to large facilities (e.g., motors, transmission and distribution, vehicles) are analyzed using manual calculation methods.
\end{abstract}

The present value (PV) of the installed cost of all EROs constituting the minimum LCC efficiency resource (i.e., cost-effective) at Fort Irwin is approximately $\$ 23.9$ million in 1994 dollars (1994\$). The PV of the energy and demand, operations and maintenance (O\&M), and replacement savings associated with this investment is approximately $\$ 87.3$ million, for an overall NPV of $\$ 63.6$ million.

This paper will describe the FEDS process and present detailed results of the comprehensive energy resource assessment conducted at Fort Irwin.

\section{WHAT IS FEDS?}

The number of conceivable energy conservation measures, fuel-switching opportunities, and renewable energy projects at a federal site is very large. The Pacific Northwest Laboratory (PNL) uses two methods to select, evaluate, and prioritize these energy resource opportunities (EROs). The first is the Facility Energy Decision Screening (FEDS) Model. FEDS is a multilevel software tool designed to provide a comprehensive approach to fuel-neutral, technology-independent, integrated (energy) resource planning and acquisition. FEDS currently has two levels-Level-1 and Level-2. Level-1 is a menu-driven DOS-based software program designed for facility energy managers as a screening tool. Level-1 assesses the likelihood of cost-effective energy projects based on high-level facility inputs and numerous assumptions. The output of Level-1 is used to assess an facility's overall energy conservation potential from the perspectives of potential energy savings, potential cost savings, and estimated investment requirement.

Level-2 is also a DOS-based software program that can be used by facility energy managers to identify, characterize, and assess individual energy projects. However, Level-2 goes to the next level of detail, providing specific information on energy and cost savings, as well as the estimated investment requirement for specific technology retrofits. Level-2 is the appropriate analysis to follow positive Level-1 results; typically, a Level-2 input file can be initiated from a Level-1 input file. Level-2 allows the user to enter facility-specific data inputs to replace the inferred default values from Level-1. These inputs form "building sets," which are groups of buildings similar in use, age, construction type, fuel use, fuel availability, or other definable characteristics. By developing building sets based on detailed facility data, Level-2 tailors the analysis to the facility and provides more accurate and detailed economic findings.

At this point in the software development, Level-1 and Level-2 analyze most major building end uses (heating, cooling, lighting, ventilation, and service hot water) including their interactive effects (e.g., the effect of a lighting technology on heating and cooling 
loads), providing specific cost, energy (and demand changes), and LCC information, by cost-effective technology.

The second method PNL uses addresses those end uses not analyzed by the FEDS software. This analytical approach is a three-step manual-calculation (hereafter referred to as "Manual") process which has been developed by PNL to make energy resource opportunity (ERO) selection, evaluation, and prioritization manageable. The steps are

- Preliminary Screening. Select promising EROs from a master list, considering the site's mission, building stock, end-use equipment characteristics, utility characteristics, climate, energy costs, and other local conditions that affect ERO viability, and recommendations from site staff.

- Cost and Performance Analysis. Establish, with a reasonable degree of accuracy, the technical and economic feasibility of each ERO that passed the preliminary screening. Perform an analysis comparing the operating and economic performance of the existing equipment and the ERO. Where applicable, include impacts on energy security and the environment in the analysis.

- Life-Cycle Cost Analysis and Prioritization. Perform an LCC analysis and rank EROs by net present value (NPV), so that a package with the optimal return on investment can be defined. If any utility cost-sharing or rebate programs exist, they can be included within this evaluation step.

All federal agencies are required to evaluate the LCC of alternative technologies when making energy investments. The LCC analysis and prioritization step used in both the Level-2 and manual methods is required by, and complies with, federal law [1]. An LCC evaluation computes the total long-run costs of alternative actions and identifies the action that maximizes the NPV of the energy investment.

\section{FORT IRWIN CHARACTERISTICS}

Fort Irwin is a roughly 1,000 square mile U.S. Army Forces Command (FORSCOM) facility situated in the Mojave Desert approximately 37 miles northeast of Barstow, California, and south of Death Valley. The main cantonment area is located near the southeastern portion of Fort Irwin. The Fort's primary mission is to operate the National Training Center (NTC). The NTC is a support facility for training of troops normally stationed at other posts throughout the United States. A total of twelve 28-day training rotations are scheduled each year. The Fort mission results in erratic energy consumption because a large portion of the Fort population is transient, moving on- and off-site as dictated by the training schedules.

The climate at Fort Irwin is classified as "high desert," with an average annual rainfall of 2.5 in., most of which falls between December and February. Summer maximum temperatures are around $104^{\circ} \mathrm{F}$, and winter minimum temperatures are around $29^{\circ} \mathrm{F}$. Annual heating and cooling degree-days (base $65^{\circ} \mathrm{F}$ ) are 2,547 and 2,272, respectively.

\section{Building Characterization}

Roughly 842 commercial buildings (not including schools) with a floor area of 3,439,606 $\mathrm{t}^{2}$ are reported in the Fort Irwin Real Property Data Base (RPL). An additional 732 housing buildings (1636 units, not including General's Quarters) with a reported area of $2,961,830 \mathrm{ft}^{2}$ contribute to the Fort's total building area of $6,401,436 \mathrm{ft}^{2}$.

Based on the RPL, the facilities at Fort Irwin may be divided into 36 building types. These building types are created by combining facilities of different facility description codes (as provided in the RPL) into larger categories with similar energy usage. This procedure minimizes the number of building types while preserving any unique or unusual building characteristics that have an effect on energy consumption.

Family housing ( 2.9 million $\mathrm{ft}^{2}$ ) is the single largest category by square footage at Fort Irwin, followed by barracks, administration, motor pools, warehouses, manufacture administration, and general shops. These building types account for more than $80 \%$ of the total building stock at Fort Irwin.

Commercial buildings are a mix of older wood frame construction and newer stone/brick construction, with some metal frame and curtain wall construction. Family housing is primarily wood frame construction with varying levels of insulation in the walls or ceilings.

\section{Electric Utility Service Characterization}

Electric service to Fort Irwin is provided by Southern California Edison (SCE). Distribution on the site consists of five 12-kV transmission lines from two substations. Both the transmission and distribution systems are overhead line systems for most of the commercial areas. Most of the family housing areas are supplied by underground lines.

The Fort Irwin electric system has approximately 610 transformers, with a total estimated nameplate capacity of more than 35,000 kVA. The losses associated with transformer operation are estimated at an average level of $272 \mathrm{~kW}$, for a total yearly loss of 2,382 MWh. 
Table 3 presents a breakdown and summary of both the energy and demand savings for the first year and full implementation of the cost-effective energy resource at Fort Irwin.

For EROs analyzed by FEDS Level-2, lighting EROA represent the greatest efficiency resource, accounting for more than $\$ 17.3$ million of the total \$63.8 million NPV and \$4.4 million of the total \$24.7 million installed cost. The remaining ERO categories have NPVs ranging from $\$ 6.1$ million to $\$ 0.9$ million, except for cooling and heating EROs, which are only marginally cost-effective with NPVs of $\$ 108,500$ and $\$ 32,400$, respectively.

For non-building EROs, vehicles represent the greatest efficiency resource, accounting for $\$ 10.1$ million of the total $\$ 63.8$ million NPV and more than $\$ 2$ million of the total $\$ 24.7$ million installed cost. The remaining non-building ERO categories have NPVs ranging from $\$ 9.4$ million to $\$ 314,000$.

For building EROs (analyzed by Level-2), the estimated annual electricity consumption at Fort Irwin is $89,100 \mathrm{MWh}$. Estimated electric demand is $30,100 \mathrm{~kW}$. Full implementation of all electric EROs results in a reduction of $14,500 \mathrm{MWh}$ and $3,600 \mathrm{~kW}$. This represents a reduction of approximately $16 \%$ over total electricity consumption and $12 \%$ over site-wide demand. The estimated annual propane consumption at Fort Irwin is $209,100 \mathrm{MBtu}$. Full implementation of all propane EROs results in net conservation of $71,000 \mathrm{MBtu}$, which represents a net conservation of $34 \%$ of total consumption. The end uses of chilled water and district hot water were not broken out by fuel. The estimated annual chilled water use is 2 million ton-hours. Full implementation of all chilled water EROs results in a reduction of 331,000 ton-hours, or $16 \%$ of total consumption. The estimated annual district hot water use 9,200

MBtu. Full implementation of all district hot water EROs results in a reduction of $7,700 \mathrm{MBtu}$, or $83 \%$ of total consumption.

For non-building EROs, the estimated annual electricity consumption at Fort Irwin is 79,800 MWh. Estimated electric demand is $399,000 \mathrm{~kW}$-month (sum of the peak demands for each month). Full implementation of all electric EROs results in a reduction of $12,200 \mathrm{MWh}$ and $58,000 \mathrm{~kW}$-month, representing a reduction of approximately $15 \%$ over total electricity consumption and $14 \%$ over site-wide demand. The estimated annual fossil fuel consumption (natural gas, No. 2 fuel oil, propane, gasoline, and diesel) at Fort Irwin is $823,800 \mathrm{MBtu}$. This total excludes any diesel and gasoline used for vehicles not addressed through EROs. Full implementation of all fossil fuel EROs results in conservation of $187,000 \mathrm{MBtu}$ and a new load of $68,800 \mathrm{MBtu}$, for a net reduction of $118,600 \mathrm{MBtu}$. This represents conservation of $23 \%$ of total consumption, a new load of $8 \%$, for an overall decrease of $14 \%$ in fossil fuel use.

\section{ENERGY PROJECT IMPLEMENTATION AT FORT IRWIN}

To meet its target of reducing overall energy consumption by $30 \%$ by the year 2005 (1985 baseline), Fort Irwin has developed a fiveyear plan and is actively pursuing base-wide energy conservation. Sources of funding for implementing these energy conservation projects include the Department of Army's Energy and Conservation Investment Program (MILCON/ECIP) and the Federal Energy Management Program (FEMP). Another potential source of funds is the utility-sponsored demand-side management (DSM) programs. The FEDS Level-2 results are used to prioritize the most cost-effective energy projects by evaluating the projects' lifecycle costs, investment requirements, and the energy savings opportunities.

\section{Five-Year Energy Plan}

Fort Irwin has developed an extended five-year energy plan that provides a timeline for implementation of energy conservation projects and identifies potential funding mechanisms. Individual energy projects identified by the FEDS process have been folded into this plan. The five-year plan is extremely dynamic, responding to the annual cycle of available funds or changes in utility DSM programs.

The detailed spreadsheet format of the FEDS Level-2 output allows for a relatively easy identification of individual energy projects that can be implemented as time-phased projects targeted to available funding sources. Specific projects can be identified by disaggregating the results either by building or end-use category or by a specific retrofit technology applied across multiple end uses.

As part of this process, the FEDS results were used to identify five energy projects that were submitted for FY95 FEMP funding. These projects, shown in Table 4, met the program requirements for simple payback and savings-to-investment ratio.

\section{Residential HVAC Evaluation}

The FEDS process was also used to evaluate alternative scenarios for heating and cooling of the existing family housing. There are 1,637 family housing units, all with basically the same propane furnace and central air conditioning systems. The options evaluated included air-source heat pump, ground-source heat pump, LPG furnace and central air, natural gas furnace and central air, and gasfired heat pump (still under development but included for comparison purposes).

Although natural gas is not currently available at Fort Irwin, HVAC options are included to compare the operating cost of natural gas 
and propane. The natural gas rate used in the analysis is an estimate based on information provided by Fort personnel and representatives of possible natural gas providers.

This ERO was analyzed manually because the Level-2 software cannot yet fully analyze EROs involving heat pumps (either air- or ground-source) or fuel switching from LPG to natural gas when natural gas is not available to the building. Therefore, all residential HVAC options were analyzed manually, using only the savings from the individual pieces of equipment.

The technical assumptions are as follows:

- The existing LPG fumaces have an average size of $50 \mathrm{KBtu} / \mathrm{h}$ (input) and efficiency of $70.5 \%$ AFUE. The existing air conditioners have an average size of 2.5 tons and efficiency of 8.0 SEER.

- The replacement equipment efficiencies are shown in Table 5.

- Existing energy consumption was calculated using previously developed energy use intensities (EUIs) [2]: 2.91 kWh/ $\mathrm{ft}^{2}$-yr for cooling and $26.37 \mathrm{kBtw} / \mathrm{ft}^{2}-\mathrm{yr}$ for heating. For an average house size of $1,800 \mathrm{ft}^{2}$, the energy consumption is $5,238 \mathrm{kWh}$ for cooling and 47.5 MBtu for heating per unit.

- Retrofit energy consumption is based on the actual equipment size and estimated run hours of each replacement unit to meet the same load as the existing equipment. The replacement equipment sizes are different from the existing equipment size in almost all cases because actual equipment was chosen for the retrofit options. Equipment sizes are given in Table 6.

- Operating hours for the existing equipment are based on the EUIs and equipment capacities as described above. Operating hours for the retrofit equipment are calculated from the existing equipment hours modified by the replacement equipment efficiencies and capacities.

The cost assumptions are as follows:

- The replacement equipment installed costs are shown in Table 7.

- O\&M costs are $\$ 75 / y r$ for all air- and ground-source heat pump options, $\$ 85 / y r$ for all furnace and air conditioner options (including the existing), and $\$ 105 / y r$ for the gas-fired heat pump option.

- The cost of natural gas is assumed to be $\$ 3.50 / \mathrm{MBtu}$.

Of the five options, the gas-fired heat pump was the winning technology (i.e., had the highest NPV) for this ERO. However, because natural gas is not now available at Fort Irwin (and it is unknown if the unit can be converted to LPG), this option is not viable at the Fort. In addition, present or future air quality laws may restrict the use of individual natural gas engines at each housing unit, and the residential gas-fired heat pump technology is still only in the testing stages and is therefore not available.

The runner-up HVAC technology is the high-efficiency ground-source heat pump. Full implementation of this ERO has an initial cost of $\$ 7,086,917$, with a savings-to-investment ratio of 1.7 and discounted payback of 9.9 years.

It is estimated that the most cost-effective implementation of this ERO will result in an increase in annual electric energy consumption of $299,851 \mathrm{kWh}$ but an accompanying decrease in propane use of 77,702 MBtu, for a total annualized energy cost savings of $\$ 479,316$ and electric demand savings of $15,226 \mathrm{~kW}$-month at an annualized value of $\$ 234,468$.

The gas-fired heat pump is the only option that would require significant additional maintenance; the oil, oil filter and spark plug must be replaced yearly at an estimated cost (materials and labor) of $\$ 105$ per unit. Replacing the furnace and air conditioner with a heat pump should result in minor O\&M savings of approximately $\$ 16,370 / \mathrm{yr}$.

\section{CONCLUSION}

Potential energy conservation measures, fuel-switching opportunities, and renewable energy projects at.facilities the size of Fort Irwin are innumerable. A practical method to systematically assess all possible combinations of energy resource opportunities is needed to make the selection, evaluation, and prioritization of individual energy projects a manageable task. The FEDS process and Level-2 software do just that.

A FEDS assessment of Fort Irwin was recently completed. Significant energy and energy-cost savings opportunities were identified that would reduce building electric energy consumption by $16 \%$ and propane consumption by $34 \%$. For non-building EROs, electric 
energy consumption would be reduced by $15 \%$; fossil-fuel consumption would decline by $14 \%$.

Individual energy projects identified using the FEDS process have been folded into a 5-year energy plan currentiy being implemented at Fort Irwin. It is anticipated that the FEDS assessment will be repeated in 1996 to reevaluate the energy conservation opportunities, given implementation of some of the recommended projects, revised energy costs, and other changing conditions at Fort Irwin.

\section{REFERENCES}

[1] 10 CFR 436. 1992. U.S. Department of Energy, "Federal Energy Management and Planning Programs." U.S. Code of Federal Regulations.

[2] Richman, E.E., J.M. Keller, A.L. Dittmer, and D.L. Hadley. 1994. Fort Irwin Integrated Resource Assessment Volume 2: Baseline Detail. PNL-9064 Vol. 2, Pacific Northwest Laboratory, Richland, Washington.

[3] Means. 1992. MEANS Building Construction Cost Data: 1992 15th Annual Edition. R.S. Means Company, Inc. Kingston, Massachusetts. 
TABLE 1: ANNUAL ENERGY CONSUMPTION AND ENERGY COST

\begin{tabular}{|l|r|r|r|r|r||}
\hline Energy Type & \multicolumn{1}{c|}{$\begin{array}{c}\text { Annual } \\
\text { Consumption }\end{array}$} & $\begin{array}{c}\text { Annual } \\
\text { Consumption } \\
\text { (MBtu) }\end{array}$ & \multicolumn{1}{c|}{$\begin{array}{c}\text { Percent of } \\
\text { Total Energy }\end{array}$} & \multicolumn{1}{c|}{$\begin{array}{c}\text { Annual } \\
\text { Cost } \\
(19945)\end{array}$} & \multicolumn{1}{c|}{$\begin{array}{c}\text { Percent of } \\
\text { Total Cost }\end{array}$} \\
\hline Electricity & $72,860 \mathrm{MWh}$ & 248,645 & 11.9 & $6,271,513$ & 52.8 \\
Propane & $2,369,487 \mathrm{gal}$ & 225,101 & 10.8 & $1,120,293$ & 9.5 \\
Gasoline & $446,098 \mathrm{gal}$ & 55,762 & 2.7 & 370,261 & 3.1 \\
Diesel & $3,718,042 \mathrm{gal}$ & 515,692 & 24.7 & $2,491,088$ & 21.0 \\
JP-4 & $770,500 \mathrm{gal}$ & 184,646 & 8.9 & 577,875 & 4.9 \\
JP-8 & $1,367,750 \mathrm{gal}$ & 853,954 & 41.0 & $1,025,813$ & 8.7 \\
Totals & - & $2,083,800$ & 100.0 & $11,856,843$ & 100.0 \\
\hline
\end{tabular}


TABLE 2: SUMMARY OF THE COST-EFFECTIVE EROS (1994S)

\begin{tabular}{|c|c|c|c|c|c|c|}
\hline ERO Category & $\begin{array}{l}\text { Presen Value } \\
\text { of Intalled } \\
\text { Cout }\end{array}$ & $\begin{array}{l}\text { Present Value of } \\
\text { Energy and } \\
\text { Demund Savings }\end{array}$ & $\begin{array}{l}\text { Present Value } \\
\text { of OseM } \\
\text { Savings }\end{array}$ & $\begin{array}{l}\text { Present Valus } \\
\text { of Replacement } \\
\text { Savings }\end{array}$ & $\begin{array}{l}\text { Present Value } \\
\text { of Total } \\
\text { Saving: }\end{array}$ & $\begin{array}{l}\text { Total Ner } \\
\text { Present } \\
\text { Value }\end{array}$ \\
\hline Lights (Level-2) & $4,393,028$ & $17,464,385$ & 0 & $4,184,358$ & $21,648,743$ & $17,255,714$ \\
\hline Vehicle: & $2,047,000$ & $5,662,859$ & $6,475,790$ & 0 & $12,138,649$ & $10,091,649$ \\
\hline Envelope & $1,400,907$ & $11,619,936$ & 0 & $-789,727$ & $10,830,209$ & $9,429,302$ \\
\hline Roof (Level-2) & $2,005,349$ & $8,131,276$ & 0 & 0 & $8,131,276$ & $6,125,922$ \\
\hline Fam. Hsg. HVAC & $7,086,917$ & $12,291,871$ & 281,903 & $-241,994$ & $12,331,780$ & $5,244,863$ \\
\hline Lighting Controls & 180,827 & $2,512,676$ & 719,268 & 0 & $3,231,943$ & $3,051,116$ \\
\hline Moton & $1,362,331$ & $4,051,014$ & $-4,133$ & $-504,490$ & $3,542,390$ & $2,180,059$ \\
\hline HVAC & 279,627 & $2,565,025$ & 0 & $-126,243$ & $2,438,782$ & $2,159,155$ \\
\hline Trans. \& Dist. & $2,543,519$ & $2,242,172$ & -109 & $2,147,346$ & $4,389,410$ & $1,845,890$ \\
\hline Hot Water (Level-2) & 188,447 & $1,743,372$ & 0 & 0 & $1,743,372$ & 1,554924 \\
\hline Wall (Level-2) & 907,261 & $1,840,887$ & 0 & 0 & $1,840,887$ & 933,622 \\
\hline Central Chillers & 354,000 & $1,273,017$ & $-25,831$ & $\mathbf{0}$ & $1,247,186$ & 893,186 \\
\hline DHW \& ACC & 118,124 & $1,001,673$ & $-32,719$ & $-53,507$ & 915,446 & 797,322 \\
\hline Wells & 210,500 & 718,156 & $-4,305$ & 51,131 & 764,981 & 554,481 \\
\hline$A / C$ & 90 & 539,429 & $-1,550$ & 0 & 537,879 & 537,789 \\
\hline Heating & 235,202 & 700,930 & 0 & 22,215 & 723,146 & 487,944 \\
\hline Controls & 150,400 & 532,652 & 0 & $-68,127$ & 464,525 & 314,125 \\
\hline Cooling (Level-2) & 165,900 & 274,395 & 0 & 0 & 274,395 & 108,496 \\
\hline Heating (Level-2) & 13,016 & 45,366 & 0 & 0 & 45,366 & 32,352 \\
\hline Totals ${ }^{(t)}$ & $23,908,628$ & $72,211,089$ & $7,408,314$ & $4,620,963$ & $87,2474,447$ & $63,625,347$ \\
\hline $\begin{array}{l}\text { Notes: } \\
\text { (a) Data of this lev } \\
\text { are shown only to } \\
\text { (b) These totals are } \\
\text { numbers above. }\end{array}$ & & & & & & the \\
\hline
\end{tabular}


TABLE 3: SUMMARY OF ENERGY AND DEMAND SAVINGS FROM EROS

\begin{tabular}{|c|c|c|c|c|c|}
\hline ERO Category & $\begin{array}{c}\text { Firt Yeax } \\
\text { Energy Sevinga } \\
\text { (MBtw) }\end{array}$ & $\begin{array}{c}\text { Firnt Year } \\
\text { Demand Savinga } \\
(k W-m o)\end{array}$ & $\begin{array}{l}\text { Full Imploment } \\
\text { Energy Savings } \\
\text { (MBw) }\end{array}$ & $\begin{array}{l}\text { Full Implement } \\
\text { Demand Savinga } \\
\text { (KW-mo) }\end{array}$ & $\begin{array}{l}\text { Annualized Energy } \\
\text { and Demand } \\
\text { Savings (1994 \$) }\end{array}$ \\
\hline Lights (Level-2) & NA & NA & 34,815 & 2,487 & $1,014,144$ \\
\hline Fam. Hog. HVAC & 76,678 & 15,226 & 76,678 & 15,226 & 713,785 \\
\hline Envelope & 21,862 & 17,099 & 21,862 & 17,099 & 674,766 \\
\hline Roof (Level-2) & NA & NA & 45,939 & 621 & 472,181 \\
\hline Vehicles & 14,638 & -180 & 14,638 & -180 & 328,840 \\
\hline Hot Water (Level-2) & NA & NA & 40,609 & 20 & 242,457 \\
\hline Motors & 7,814 & 7,343 & 7,814 & 7,343 & 235,241 \\
\hline HVAC & 15,058 & 1,690 & 15,058 & 1,690 & 148,950 \\
\hline Lighting Controls & 5,992 & 0 & 5,992 & 0 & 145,910 \\
\hline Trans. \& Dist. & 2,203 & 3,708 & 6,076 & 7,223 & 130,202 \\
\hline Wall (Level-2) & NA & NA & 10,653 & 123 & 106,898 \\
\hline Central Chillers & 1,099 & 2,110 & 1,099 & 2,110 & 73,924 \\
\hline DHW \& AC & 4,345 & 2,198 & 4,345 & 2,198 & 58,167 \\
\hline Wells & 0 & 1,097 & 0 & 1,097 & 41,703 \\
\hline Heating & 4,682 & 727 & 4,713 & 742 & 40,703 \\
\hline Cooling (Level-2) & NA & NA & 962 & 143 & 35,400 \\
\hline $\mathrm{A} / \mathrm{C}$ & 935 & 1,129 & 935 & 1,129 & 31,324 \\
\hline Controls & 1,508 & 2,186 & 1,508 & 2,186 & 30,931 \\
\hline Heating (Level-2) & NA & NA & -71 & 0 & 3,976 \\
\hline Totals: & 156,813 & 54,331 & 293,623 & 61,256 & $4,529,501$ \\
\hline
\end{tabular}




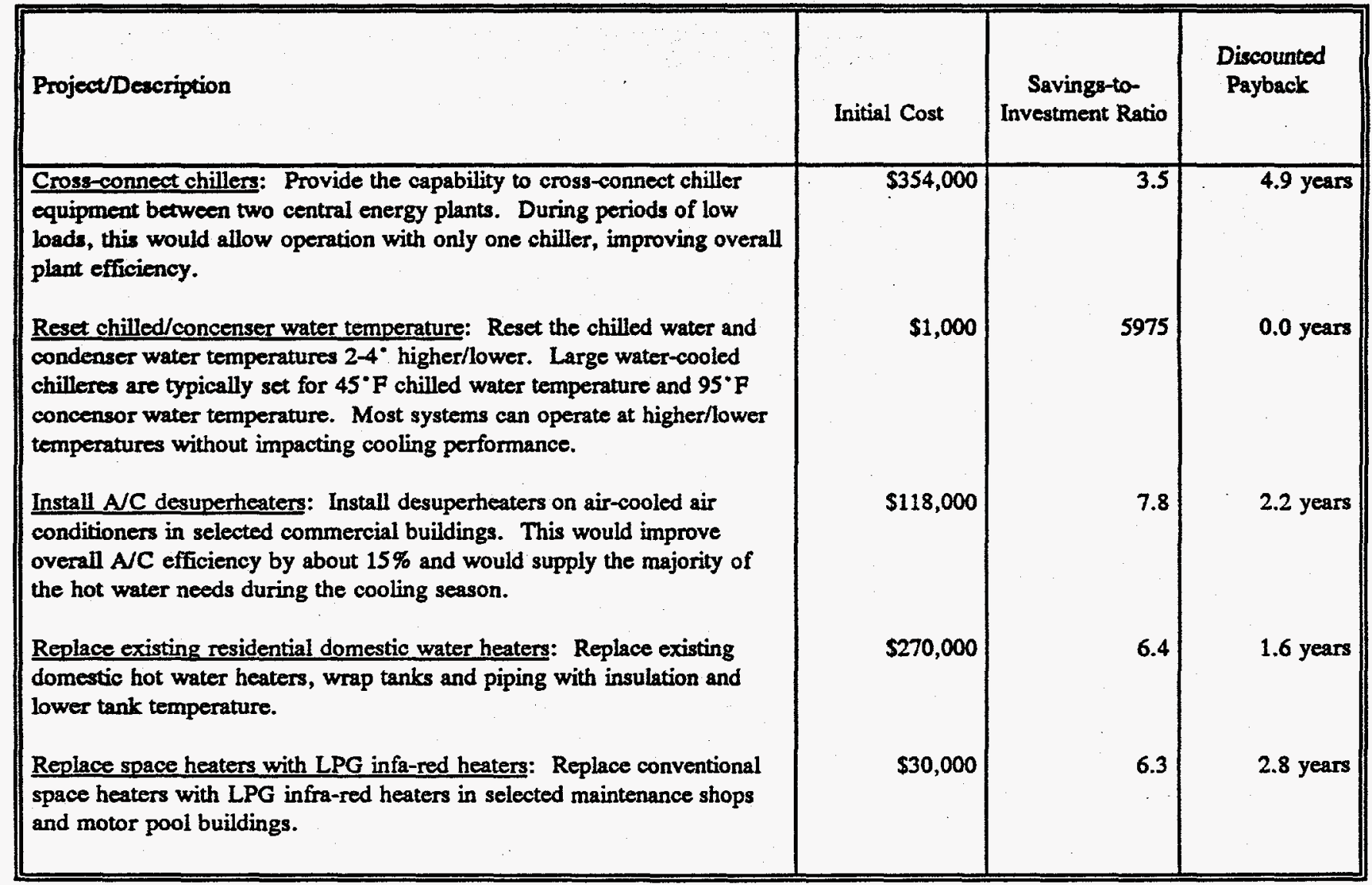


TABLE 5: EFFICIENCY RATINGS OF REPLACEMENT HVAC EQUIPMENT

\begin{tabular}{|l|c|c|}
\hline Replacement Equipment & Cooling Eff. & Heating Eff. \\
\hline Min. Compliance Air-source Heat Pump & 10.0 SEER & 7.0 HSPF \\
High Eff. Air-source Heat Pump & 15.4 SEER & 8.3 HSPF \\
Avg. Eff. Ground-source Heat Pump & 13.3 EER & 2.8 COP \\
High Eff. Ground-source Heat Pump & 16.0 EER & 3.5 COP \\
Min. Compliance Furnace and AV & 10.0 SEER & $78.0 \%$ AFUE \\
High Eff. Furnace and AVC & 15.7 SEER & $92.6 \%$ AFUE \\
Gas-Fired Heat Pump & 1.1 COP & 1.3 COP \\
\hline
\end{tabular}

Note: (1) Efficiencies for the LPG and natural gas furnace and central air conditioner options are assumed the same; the only difference for these two options is the price of fuel.

(2) Additional notes on ground-source heat pumps: 1) There are no efficiency standards for groundsource heat pumps, so an average efficiency unit was chosen to represent the minimum compliance case, 2) Since the ground temperature remains fairly constant, the given efficiencies are assumed to represent seasonal values (EER = SEER).

TABLE 6: REPLACEMENT EQUIPMENT SIZES

\begin{tabular}{|l|c|c|}
\hline \multicolumn{1}{|c|}{ Replacement Equipment } & $\begin{array}{c}\text { Cooling Cap. } \\
(\mathrm{KBtu} / \mathrm{h})\end{array}$ & $\begin{array}{c}\text { Heating Cap. } \\
\text { (KBtu/h) }\end{array}$ \\
\hline Minimum Compliance Air-Source Heat Pump & 28.2 & 27.4 \\
High-Efficiency Air-Source Heat Pump & 29.0 & 29.0 \\
Average-Efficiency Ground-Source Heat Pump & 30.2 & 20.8 \\
High-Efficiency Ground-Source Heat Pump & 31.2 & 21.2 \\
Minimum Compliance Furnace and AV & 28.6 & 40.0 \\
High-Efficiency Furnace and AC & 30.8 & 37.0 \\
Gas-Fired Heat Pump & 36.0 & 53.5 \\
\hline
\end{tabular}

TABLE 7: INSTALLED COST OF REPLACEMENT EQUIPMENT

\begin{tabular}{|l|c|c|}
\hline \multicolumn{1}{|c|}{ Replacement Equipment } & Material & Labor (1994 \\
$\mathbf{( 1 9 9 4} \$ \mathbf{~})$ & $\mathbf{\$}$ \\
\hline Minimum Compliance Air-Source Heat Pump & $\$ 2,180$ & $\$ 559$ \\
High-Efficiency Air-Source Heat Pump & $\$ 5,175$ & $\$ 559$ \\
Average-Efficiency Ground-Source Heat Pump & $\$ 3,000$ & $\$ 559$ \\
High-Efficiency Ground-Source Heat Pump & $\$ 3,770$ & $\$ 559$ \\
Minimum Compliance Furnace and AVC & $\$ 1,483$ & $\$ 468$ \\
High-Efficiency Furnace and A/C & $\$ 4,725$ & $\$ 468$ \\
Gas-Fired Heat Pump & $\$ 5,000$ & $\$ 750$ \\
\hline
\end{tabular}

Note: Material costs are from manufacturers' catalogs and sales representatives. Labor costs are from $R$. S. Means [3]. All costs include 15\% overhead and profit. Material and labor costs for the ground-source heat pump excavation and piping are included in the material cost column above. 